\title{
The Anti-Diabetic Potential of Thermally Treated Garlic, Turmeric, and Ginger in Pre-Diabetic Male Wistar Rat Model
}

\author{
Fredreana Hester, M. Verghese*, S. Willis, A. Baldwin, M. Reid, L. Shackelford, R. Sunkara, \\ L. Walker
}

Food and Animal Sciences, Alabama A \& M University, Normal, AL, USA

Email: *martha.verghese@aamu.edu

How to cite this paper: Hester, F., Verghese, M., Willis, S., Baldwin, A., Reid, M., Shackelford, L., Sunkara, R. and Walker, L. (2018) The Anti-Diabetic Potential of Thermally Treated Garlic, Turmeric, and Ginger in Pre-Diabetic Male Wistar Rat Model. Food and Nutrition Sciences, 9, 420-431. https://doi.org/10.4236/fns.2018.94033

Received: November 22, 2017

Accepted: April 27, 2018

Published: April 30, 2018

Copyright ( $\odot 2018$ by authors and Scientific Research Publishing Inc. This work is licensed under the Creative Commons Attribution International License (CC BY 4.0).

http://creativecommons.org/licenses/by/4.0/

\section{(c) (i) Open Access}

\begin{abstract}
Spices (turmeric (T), ginger (GI), and garlic (GA) (TGG)) have been used for centuries for food preservation, flavors, and medicinal properties. Research suggests that TGG contain potent antioxidants that may prevent and/or delay chronic diseases such as cancer, diabetes, and heart diseases. Heat treatment of spices may potentially increase antioxidative activity by modifying the inherent chemical structure of potent antioxidative compounds in spices. The purpose of this study was to determine the anti-diabetic potential of thermally treated TGG on Wistar male rats. Two-week-old male Wistar rats were randomly assigned to 8 groups $(\mathrm{N}=24, \mathrm{n}=3)$ including control AIN-93G Diet (C) and high fat (HFD) and high sugar (HS) (glucose 10\%) diet and treatment HFD/HS diets containing T, GA, GI (1\% and 2\%) singly for 11 weeks. Weekly feed intake, body weight, and blood glucose levels were recorded. Rats were sacrificed at 13 wks. by $\mathrm{CO}_{2}$ asphyxiation. Liver, pancreas, adipose (thigh), cecum, femur, urine, and serum samples were collected for quantitative determination of detoxification and antioxidative enzyme analysis, bone mineralization, and cholesterol using standard protocol. Of spice-incorporated diets, rats fed turmeric (1\%) exhibited the lowest reduction in blood glucose levels at $90 \mathrm{mg} / \mathrm{dL}$ compared to the control $58 \mathrm{mg} / \mathrm{dL}$. Additionally rats fed TGG at both concentrations resulted in an induction of antioxidant (GSH) and antioxidant enzyme (GPx) activity with significantly $(p \leq 0.05)$ higher levels compared to the control. Serum total cholesterol levels were lower in spice-incorporated diets compared to control HFD/HS fed rats. Therefore, the use of thermal application on spices presents promise in potentiating the antioxidant effects and thereby their potential health promoting properties.
\end{abstract}

\section{Keywords}

Type 2 Diabetes, Bioactive Compounds, Wistar Rats, Spices 


\section{Introduction}

Diabetes is a chronic disease characterized by hyperglycemia due to insufficient and/or ineffective insulin secretion [1]. Individuals with diabetes are at an increased risk for the development of chronic diseases and health complications such as cardiovascular disease, blindness, amputation, and kidney failure [2]. Prediabetes or Impaired Glucose Tolerance (IGF) is a precursor to diabetes affecting 86 million Americans [3]. Prediabetes is a condition where individuals' blood glucose levels are above normal levels yet not classified as being diabetic. According to Babey et al. [4] it is estimated that one in three adults in the US has prediabetes and without intervention $30 \%$ of these individuals will develop type 2 diabetes and $70 \%$ will develop it within their lifetime. High incidences of diabetes have been attributed to diet, specifically the western diet [5] [6]. The western diet is a composed of high fat and high sugar intakes and low intakes of fruits, vegetables, and whole grains. Maintaining a healthy diet is critical in the prevention and/or treatment of diabetes as increased consumption of fruits and vegetables has shown to have a reduced incidence of the development of diabetes [7] [8] [9]. Research has shown that spices, herbs, and their extracts possess antimicrobial, anti-inflammatory, anti-rheumatic, lipid-lowering, hepatoprotective, nephroprotective, antimutagenic and anticancer activities [10] [11] [12]. Research has shown garlic, turmeric, and ginger to contain anti-diabetic properties attributed to the presence of phytochemicals curcuminoids, gingerols, and sulfur containing compounds [13] [14] [15] [16]. Wongsa et al. [17] reported that both garlic and turmeric showed potential inhibition against $\alpha$-amylase and $\alpha$-glucosidases ranging from $0.00 \%-58.38 \%$ and $6.75 \%-100.00 \%$, and may be good candidates to help treat and manage the early stages of hyperglycemia. Additionally these spices have shown to lower serum glucose, insulin, and triglycerides in male wistar rats [13]. Although these spices have been used for centuries for their medicinal properties additional research is required to substantiate these therapeutic and pharmacological claims. Therefore the purpose of this study was to determine the anti-diabetic potential of thermally treated garlic, turmeric, and ginger on pre-diabetic wistar male rats.

\section{Materials and Methods}

\section{Spice Preparation}

Garlic (Allium sativum), ginger (Zingiberofficinale), and turmeric (Curcuma longa) powders were purchased from Monterey Bay Spice Company, (Watsonville, CA). Spices were subjected to direct heat treatments for experimentation. Direct heat-treated turmeric, ginger, and garlic powders were conducted by stovetop toasted as follows garlic 1 minute toasting $\left(70^{\circ} \mathrm{C}-100^{\circ} \mathrm{C}\right)$, ginger 5 minute toasting $\left(70^{\circ} \mathrm{C}-130^{\circ} \mathrm{C}\right)$ and turmeric 5 minute toasting $\left(70^{\circ} \mathrm{C}-130^{\circ} \mathrm{C}\right)$ based upon preliminary chemical analysis. Spices were then incorporated in an HFD/HS AIN-93G diet singly at $1 \%$ and $2 \%$ concentrations.

\section{Animal Care}


A total of 24 two week old Wistar male rats (Harlan Laboratories, Indianapolis, IN) weighing 209 - 253 g were housed in an environmentally controlled animal care facility for the duration of the study. The temperature and relative humidity were kept at $20^{\circ} \mathrm{C} \pm 1{ }^{\circ} \mathrm{C}$ and $50 \%$. Light and dark cycles were at 12 hours each. The rats were allowed a 2 -week acclimation period and fed the American Institute of nutrition diet (AIN-93G) and water [18]. At 6 weeks of age, rodents (Wistar males) were housed in stainless steel cages (2/cage). After acclamation rodents were randomly assigned to groups each consisting of 3 rats followed by the introduction of high fat (40\% Lard/soybean) and high sugar diet (10\% glucose). Spices and fat incorporated into the basal AIN-93G diet (Table 1) were replaced by corn starch. Weekly weight and blood glucose measurements conducted until the end of the experimental period.

Rats had ad-libitum access to treatment diets throughout the experimental period (11 weeks). At the end of the testing period (11 weeks) a single collection of blood was taken followed by immediate euthanasia by carbon dioxide asphyxiation. Vital organs of each rat were excised, blotted and weighed and the organ/body weight ratios calculated. The animals in the study were handled in accordance with the AAMU guidelines for the protection and care of animals. The Institute of Animal Care and Use Committee (IACUC) committee approved the protocol for the study before beginning experiment.

Table 1. Short term animal feed diet.

\begin{tabular}{|c|c|c|c|c|c|c|c|c|}
\hline \multicolumn{9}{|c|}{ AIN-93G Composition Diets } \\
\hline Ingredient & Control (g) & HFD/HS-Control & $\begin{array}{c}\text { HFD/HS-T } \\
1 \%\end{array}$ & $\begin{array}{c}\text { HFD/HS-T } \\
2 \%\end{array}$ & $\begin{array}{c}\mathrm{HFD} / \mathrm{HS}-\mathrm{GA} \\
1 \%\end{array}$ & $\begin{array}{c}\mathrm{HFD} / \mathrm{HS}-\mathrm{GA} \\
2 \%\end{array}$ & $\begin{array}{c}\text { HFD/HS-GI } \\
1 \%\end{array}$ & $\begin{array}{c}\text { HFD/HS-GI } \\
2 \%\end{array}$ \\
\hline Cornstarch & 397.5 & 257.5 & 247.5 & 237.5 & 247.5 & 237.5 & 247.5 & 237.5 \\
\hline Sucrose & 100 & 100 & 100 & 100 & 100 & 100 & 100 & 100 \\
\hline Casein & 200 & 200 & 200 & 200 & 200 & 200 & 200 & 200 \\
\hline Fiber & 50 & 50 & 50 & 50 & 50 & 50 & 50 & 50 \\
\hline Soybean Oil & 70 & 105 & 105 & 105 & 105 & 105 & 105 & 105 \\
\hline Lard & 0 & 105 & 105 & 105 & 105 & 105 & 105 & 105 \\
\hline Mineral Mix (G) & 35 & 35 & 35 & 35 & 35 & 35 & 35 & 35 \\
\hline Vitamin Mix & 10 & 10 & 10 & 10 & 10 & 10 & 10 & 10 \\
\hline L-Cysteine & 3 & 3 & 3 & 3 & 3 & 3 & 3 & 3 \\
\hline Choline & 2.5 & 2.5 & 2.5 & 2.5 & 2.5 & 2.5 & 2.5 & 2.5 \\
\hline Garlic & 0 & 0 & 0 & 0 & 10 & 20 & 0 & 0 \\
\hline Ginger & 0 & 0 & 0 & 0 & 0 & 0 & 10 & 20 \\
\hline Turmeric & 0 & 0 & 10 & 20 & 0 & 0 & 0 & 0 \\
\hline TOTAL & 1000 & 1000 & 1000 & 1000 & 1000 & 1000 & 1000 & 1000 \\
\hline
\end{tabular}




\section{Organs \& Biological Samples Preparation}

During autopsy, blood was taken from rats from each group, and the serum separated and cholesterol and glucose were determined using standard kits (Cayman Chemicals Ann Arbor, MI, USA). Urinary pH was determined by measurement with $\mathrm{pH}$ testing strips obtained from EM Science (Gibbstown, N.J.). Test strips were immersed in urine samples for 2 minutes and $\mathrm{pH}$ was recorded. Femurs were excised from rats and weights of bones, bone length, and diameter will be recorded. Selected minerals ( $\mathrm{Mg}, \mathrm{Ca}, \mathrm{P}, \mathrm{Zn}$, and $\mathrm{Fe}$ ) were analyzed by inductively coupled plasma (ICP) (AOAC 984.27).

\section{Antioxidant and Detoxification Enzymes}

Liver samples were used to measure detoxification and antioxidant enzymes Glutathione (GSH), Glutathione S-transferase (GST), Glutathione peroxidase (GPx), Superoxide dismutase (SOD), and catalase (CAT) of rat livers according to the manufacturer's instructions (Cayman Chemical Company, Ann Arbor, MI). Briefly, one gram of liver was homogenized in $10 \mathrm{ml}$ of TRIS hydrochloric acid mixture. Following homogenization, liver solutions were centrifuged for 20 minutes at $5000 \mathrm{xg}$ at $4^{\circ} \mathrm{C}$. The supernatant was decanted into test tubes. Following decantation, the precipitant was washed with an additional amount of TRIS hydrochloric acid and centrifuged for $20 \mathrm{~min}$ at 10,000 XG. The supernatant was collected and used for analysis.

\section{Statistical Analysis}

Results are presented as means \pm SEM using SAS system version 9.3.ANOVA was used to determine any significant differences among the treatment groups. Significance was determined at $P \leq 0.05$. The means were separated using Tukey's Studentized Range Test.

\section{Results \& Discussion}

Blood glucose levels were recorded weekly for all treatment groups for 11 weeks (Figure 1 and Figure 2). When comparing rats fed $1 \%$ spice-incorporated diets to the control (Figure 1), spice diets resulted in a gradual decline of blood glucose levels throughout the study (11 weeks). Initial blood glucose levels ranged from a high of $291 \mathrm{mg} / \mathrm{dL}$ (GI 1\%) to a low of $107 \mathrm{mg} / \mathrm{dL}$ (T 1\%). Final blood glucose levels ranged from a low of $57 \mathrm{mg} / \mathrm{dL}$ (control) to a high of $164 \mathrm{mg} / \mathrm{dL}$ (GI 1\%). Although all spice diets resulted in higher blood glucose levels compared to the control, turmeric $1 \%(90 \mathrm{mg} / \mathrm{dL})$ diet lowered blood glucose levels to a level closest to control $(57.66 \mathrm{mg} / \mathrm{dL})$ fed rats.

When comparing $2 \%$ spice-incorporated diets to the control (Figure 2), all spice diets resulted in higher blood glucose compared to the control (no $\mathrm{HFD} / \mathrm{HS}$ ). Initial blood glucose levels ranged from a high of $178 \mathrm{mg} / \mathrm{dL}$ (control) to a low of $99 \mathrm{mg} / \mathrm{dl}$ (GA 2\%). Final blood glucose levels ranged from a low of 57 $\mathrm{mg} / \mathrm{dL}$ (control) to a high of $150 \mathrm{mg} / \mathrm{dL}$ (GI 2\%). Among the dietary treatments, rats fed ginger at $1 \% \& 2 \%$ showed higher blood glucose levels.

Table 2 and Figure 3 show the effect of feeding control and treatment diets 
on bone mineralization in Wistar male rats. Bone minerals ( $\mathrm{Fe}, \mathrm{Zn}, \mathrm{Mg}, \mathrm{Mn}, \mathrm{Cu}$, $\mathrm{K}, \mathrm{Ca}$, and $\mathrm{P}$ ) were analyzed. There were no significant differences found in bone

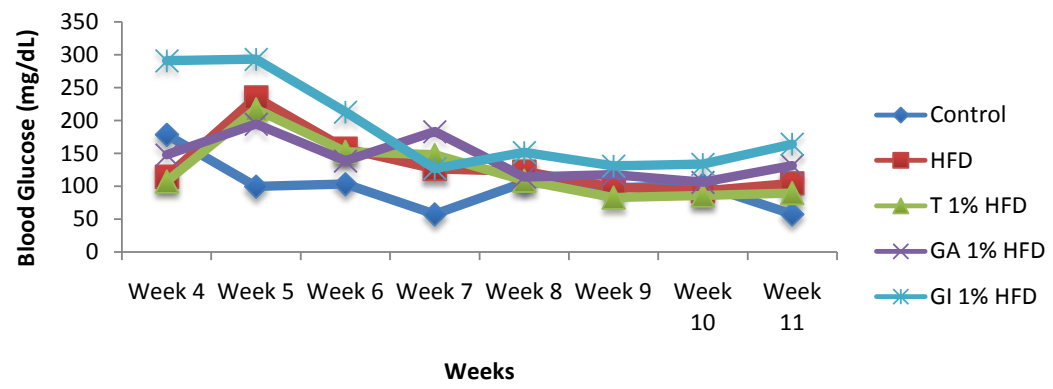

Figure 1. Rat blood glucose data for control, HFD, low (1\%) concentration thermally treated groups. Abbreviations: $\mathrm{HFD}=$ High fat diet, $\mathrm{HS}=$ High sugar, $\mathrm{T} 1=$ $\mathrm{HFD} / \mathrm{HS}+$ turmeric $1 \%, \mathrm{~T} 2=\mathrm{HFD} / \mathrm{HS}+$ turmeric $2 \%, \mathrm{GA} 1=\mathrm{HFD} / \mathrm{HS}+$ garlic $1 \%$, GA $2=\mathrm{HFD} / \mathrm{HS}+$ garlic $2 \%$, GI $1=\mathrm{HFD} / \mathrm{HS}+$ ginger $1 \%$, GI $2=\mathrm{HFD} / \mathrm{HS}$ + ginger $2 \%$.

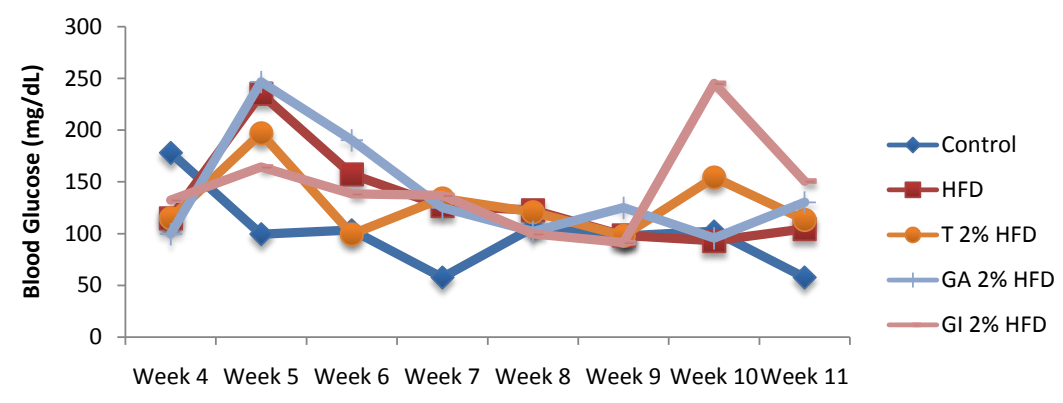

Weeks

Figure 2. Blood glucose data for rats fed control, HFD, high (2\%) concentration thermally treated spices. Abbreviations: HFD $=$ High fat diet, HS $=$ High sugar, $\mathrm{T} 1=\mathrm{HFD} / \mathrm{HS}+$ turmeric $1 \%, \mathrm{~T} 2=\mathrm{HFD} / \mathrm{HS}+$ turmeric $2 \%, \mathrm{GA} 1=\mathrm{HFD} / \mathrm{HS}+$ garlic $1 \%$, GA $2=\mathrm{HFD} / \mathrm{HS}+$ garlic $2 \%$, GI $1=\mathrm{HFD} / \mathrm{HS}+$ ginger $1 \%$, GI $2=$ $\mathrm{HFD} / \mathrm{HS}+$ ginger $2 \%$.

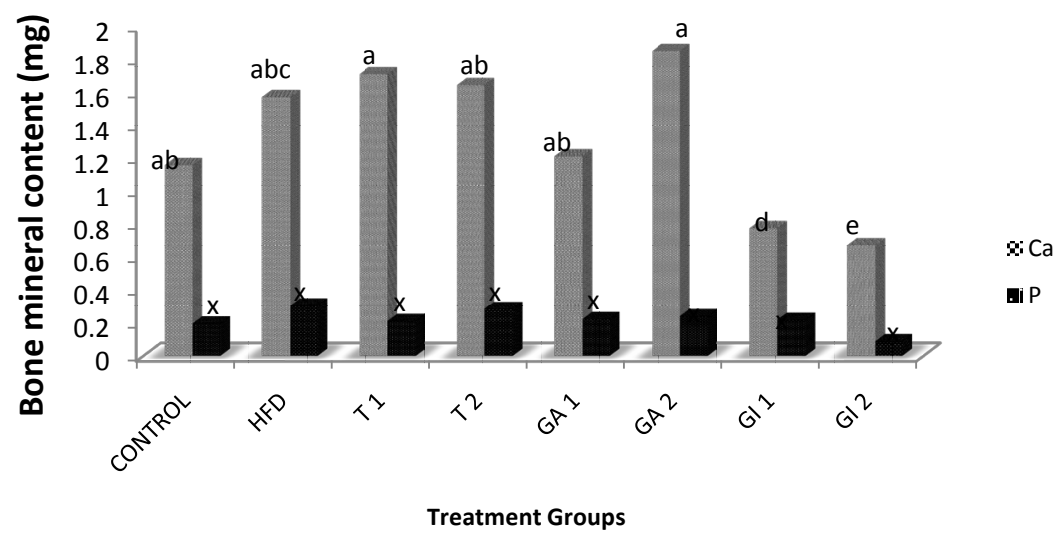

Figure 3. Bone mineralization (calcium and phosphorus) in rats. abc, xBars with superscripts are significantly different $(p \leq 0.05)$. Abbreviations: HFD $=$ High fat diet, $\mathrm{HS}=$ High sugar, $\mathrm{T} 1=\mathrm{HFD} / \mathrm{HS}+$ turmeric $1 \%, \mathrm{~T} 2=\mathrm{HFD} / \mathrm{HS}+$ turmeric $2 \%, \mathrm{GA} 1=\mathrm{HFD} / \mathrm{HS}+$ garlic $1 \%$, GA $2=\mathrm{HFD} / \mathrm{HS}+$ garlic $2 \%$, GI $1=\mathrm{HFD} / \mathrm{HS}$ + ginger $1 \%$, GI $2=\mathrm{HFD} / \mathrm{HS}+$ ginger $2 \% \mathrm{Ca}=$ calcium, $\mathrm{P}=$ phosphorus. 
Table 2. Bone mineralization in rats.

\begin{tabular}{|c|c|c|c|c|c|c|}
\hline & $\mathrm{Fe}(\mathrm{mg})$ & $\mathrm{Zn}(\mathrm{mg})$ & $\mathrm{Mg}(\mathrm{mg})$ & $\mathrm{Mn}$ (mg) & $\mathrm{Cu}(\mathrm{mg})$ & $\mathrm{K}(\mathrm{mg})$ \\
\hline CONTROL & $0.00015^{\mathrm{a}} \pm 0$ & $0.00048^{\mathrm{ab}} \pm 0$ & $0.0085^{\mathrm{ab}} \pm 0$ & $0.000013^{\mathrm{a}} \pm 0$ & $0.000016^{\mathrm{b}} \pm 0$ & $0.0062^{\mathrm{ab}} \pm 0$ \\
\hline HFD/HS & $0.00033^{\mathrm{a}} \pm 0$ & $0.00067^{\mathrm{a}} \pm 0$ & $0.012^{\mathrm{a}} \pm 0$ & $0.0000046^{\mathrm{a}} \pm 0$ & $0.000014^{\mathrm{b}} \pm 0$ & $0.0090^{\mathrm{a}} \pm 0$ \\
\hline $\mathrm{HFD} / \mathrm{HS}+\mathrm{T} 1 \%$ & $0.00019^{\mathrm{a}} \pm 0$ & $0.00043^{\mathrm{ab}} \pm 0$ & $0.0078^{\mathrm{ab}} \pm 0$ & ND & $0.0000092^{\mathrm{b}} \pm 0$ & $0.0047^{\mathrm{ab}} \pm 0$ \\
\hline HFD/HS + T 2\% & $0.00029^{\mathrm{a}} \pm 0$ & $0.00062^{\mathrm{ab}} \pm 0$ & $0.011^{\mathrm{ab}} \pm 0$ & $0.0000107^{\mathrm{a}} \pm 0$ & $0.000040^{\mathrm{a}} \pm 0$ & $0.0090^{\mathrm{a}} \pm 0$ \\
\hline $\mathrm{HFD} / \mathrm{HS}+\mathrm{GA} 1 \%$ & $0.00024^{\mathrm{a}} \pm 0$ & $0.00046^{\mathrm{ab}} \pm 0$ & $0.0083^{\mathrm{ab}} \pm 0$ & $0.0000032^{\mathrm{a}} \pm 0$ & $0.000014^{\mathrm{b}} \pm 0$ & $0.0055^{\mathrm{ab}} \pm 0$ \\
\hline $\mathrm{HFD} / \mathrm{HS}+\mathrm{GA} 2 \%$ & $0.00026^{\mathrm{a}} \pm 0$ & $0.00049^{\mathrm{ab}} \pm 0$ & $0.0089^{\mathrm{ab}} \pm 0$ & $0.0000034^{\mathrm{a}} \pm 0$ & $0.000021^{b} \pm 0$ & $0.0051^{\mathrm{ab}} \pm 0$ \\
\hline HFD/HS + GI 1\% & $0.00025^{\mathrm{a}} \pm 0$ & $0.00046^{\mathrm{ab}} \pm 0$ & $0.0084^{\mathrm{ab}} \pm 0$ & ND & $0.000019^{b} \pm 0$ & $0.0050^{\mathrm{ab}} \pm 0$ \\
\hline $\mathrm{HFD} / \mathrm{HS}$ + GI $2 \%$ & $0.000058^{\mathrm{a}} \pm 0$ & $0.00018^{\mathrm{ab}} \pm 0$ & $0.0036^{\mathrm{ab}} \pm 0$ & ND & $0.0000067^{\mathrm{b}} \pm 0$ & $0.0021^{\mathrm{c}} \pm 0$ \\
\hline
\end{tabular}

${ }^{\text {abc } V a l u e s ~ w i t h ~ s u p e r s c r i p t s ~ i n ~ c o l u m n s ~ a r e ~ s i g n i f i c a n t l y ~ d i f f e r e n t ~}(p \leq 0.05)$. Results expressed as Means $\pm \mathrm{SEM}, \mathrm{n}=3$. Abbreviations: $\mathrm{T}=\mathrm{Turmeric}, \mathrm{GA}=$ Garlic, GI = Ginger, $\mathrm{HFD}=$ High fat diet, $\mathrm{HS}=$ High sugar, $\mathrm{Mn}=$ manganese, $\mathrm{Cu}=$ copper, $\mathrm{K}=$ potassium.

mineralization for Fe, $\mathrm{Zn}, \mathrm{Mg}, \mathrm{Mn}$, and P. Rats fed HFD/HS + Turmeric $2 \%$ had significantly $(p \leq 0.05)$ higher levels of copper in bones compared to other rats fed treatment and control fed diets. While rats fed HFD/HS + Ginger 2\% had significantly $(p \leq 0.05)$ lower levels of potassium compared to other treatment and control fed rats. Bone Ca levels (Figure 3 ) were significantly $(p \leq 0.05)$ lower in rats fed $\mathrm{HFD} / \mathrm{HS}+$ ginger $1 \% \& 2 \%$, compared to other groups. Ginger is more fibrous as a spice compared to both garlic and turmeric. Studies [19] [20] have shown that fiber consumption may interfere with calcium absorption and bioavailability, due to fiber chelating calcium making it unavailable for use and then excreted.

Antioxidant and detoxification enzyme activities in Wistar rats (hepatic tissues) are reported in Figures 4-8. Catalase activity (CAT) was significantly ( $p \leq$ $0.05)$ higher in control $(2839.14 \mathrm{nmol} / \mathrm{min} / \mathrm{mL})$ fed rats compared to the rats fed treatment diets (Figure 4). Rats fed HFD/HS diets had significantly $(p \leq 0.05)$ higher CAT activity compared to rats fed HFD/HS + Garlic 2\% (766.99 $\mathrm{nmol} / \mathrm{min} / \mathrm{mL}$ ). However, there were no significant differences among the other treatment groups. There were no significant differences seen in SOD activity (Figure 5). However, all treatment diets resulted in higher SOD activity compared to the control. SOD activity ranged from a low of $761.32 \mathrm{U} / \mathrm{mL}$ (control diet) to a high of $947.68 \mathrm{U} / \mathrm{mL}$ (HFD/HS + Ginger 1\% diet). GPx activity (Figure 6$)$ was significantly $(p \leq 0.05)$ induced in rats fed spice-incorporated diets compared to the control. Highest GPx activity was seen in rats fed HFD/HS + Ginger $2 \%$ diet $(144.32 \mathrm{~mol} / \mathrm{min} / \mathrm{mL})$. SOD serves as a first line of defense, and catalyzes the conversion of the superoxide radical into $\mathrm{H}_{2} \mathrm{O}_{2}$, which further breaks down to $\mathrm{H}_{2} \mathrm{O}$ and $\mathrm{O}_{2}$ by CAT and GPx. Our findings showed that rats fed spice-incorporated diets showed a low induction of SOD yet significantly ( $p \leq$ 0.05 ) higher induction of GPx for detoxification. There was also no dose dependent response observed in the induction of enzymatic activity between $1 \%$ and $2 \%$ diets. 


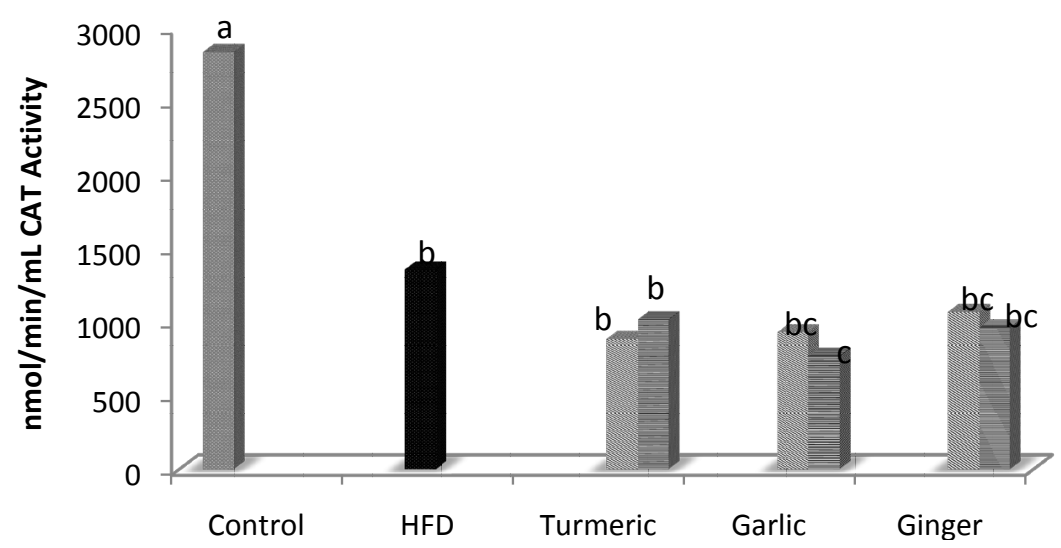

Figure 4. Catalse activity in wistar male rats. ${ }^{\text {abc }}$ Bars with superscripts are significantly different $(p \leq 0.05)$. Abbreviations: HFD = High fat diet.

$$
1 \%=2 \%
$$

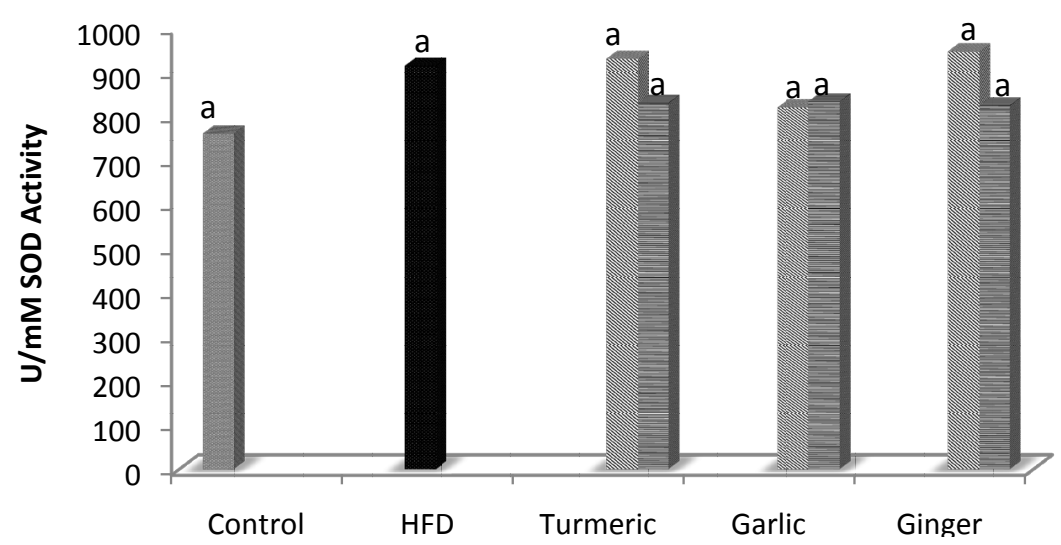

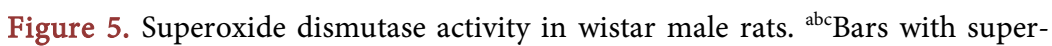
scripts are significantly different $(p \leq 0.05)$. Abbreviations: HFD $=$ High fat diet.

$$
1 \%=2 \%
$$

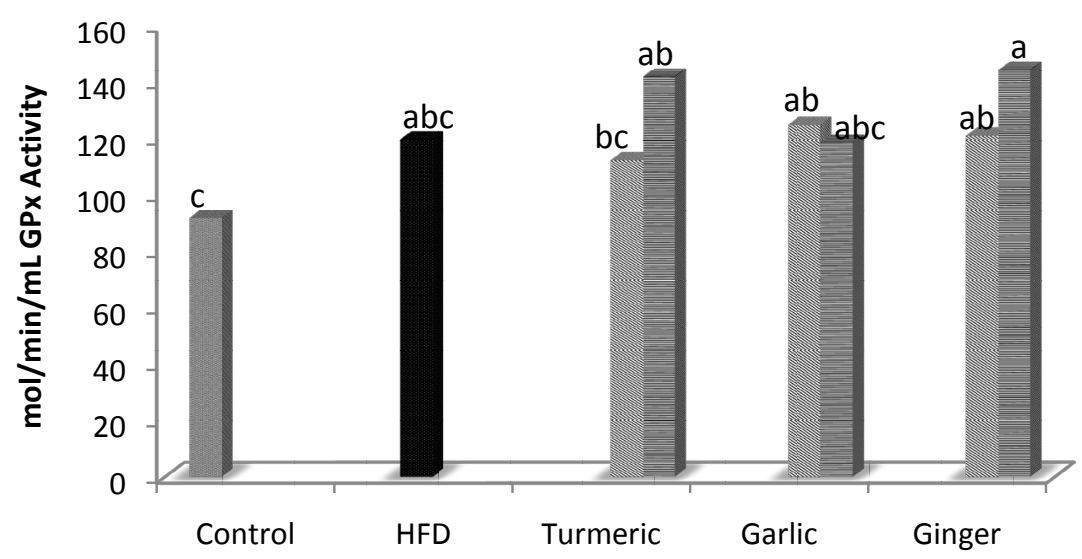

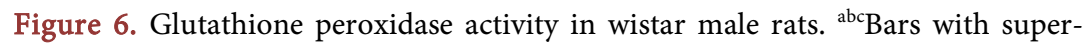
scripts are significantly different $(p \leq 0.05)$. Abbreviations: HFD $=$ High fat diet. 


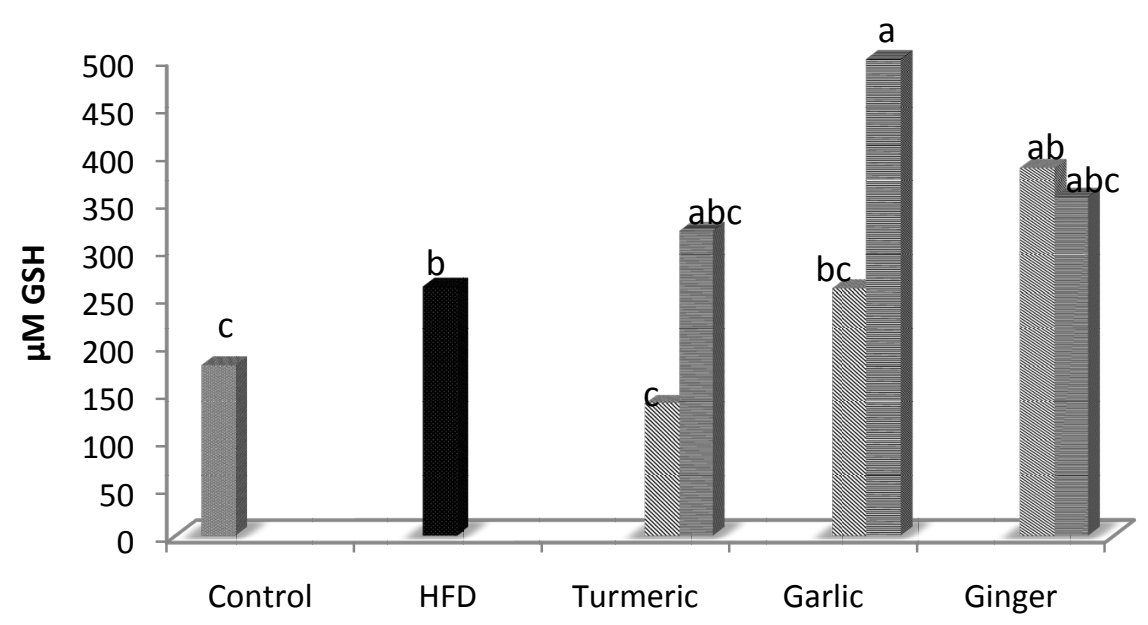

Figure 7. Glutathione levels in wistar male rats. ${ }^{\text {abc }}$ Bars with superscripts are significantly different $(p \leq 0.05)$. Abbreviations: HFD = High fat diet.

$$
r 1 \%=2 \%
$$

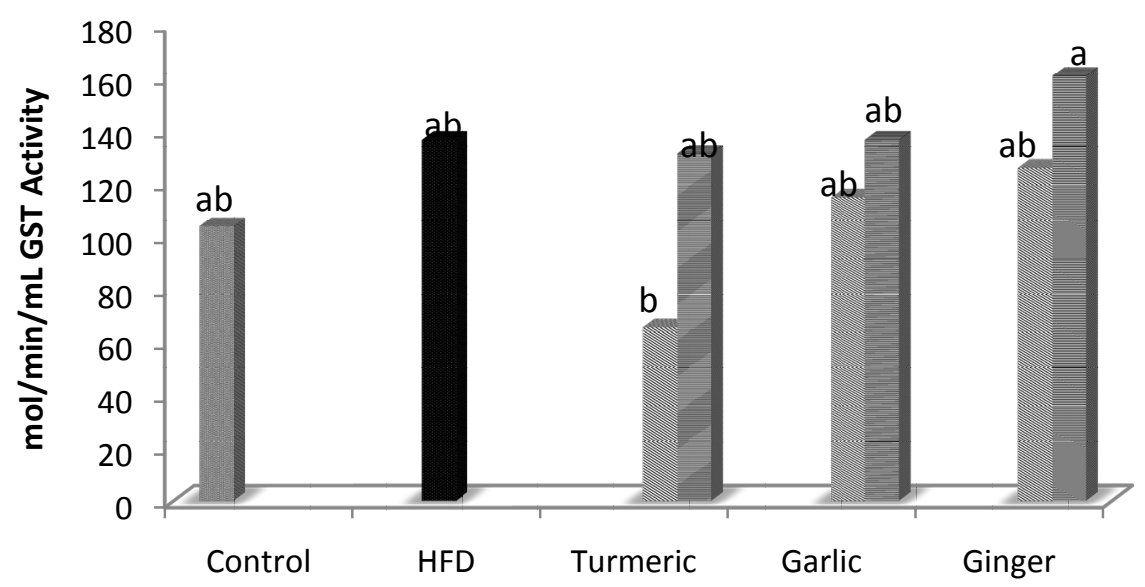

Figure 8. Glutathione S-transferase activity in wistar male rats. ${ }^{\text {abc }}$ Bars with superscripts are significantly different $(p \leq 0.05)$. Abbreviations: HFD $=$ High fat diet.

The route of detoxification among endogenous enzymes expressed may vary depending on a number of factors including vehicle introduced, dietary components, and genetic predispositions. Wohaieb \& Godin [21] showed that enzymes (SOD, GPx, and CAT) in insulin treated and non-treaded diabetic Wistar rats, significantly $(p \leq 0.05)$ higher induction of SOD and CAT compared to GPx. While Suryanarayana et al. [22] reported similar results compared to our study where they fed curcumin to STZ-induced Wistar rats, reporting significantly ( $p$ $\leq 0.05$ ) higher GPx activity in liver tissues compared to CAT activity.

Figure 7 and Figure 8 show GSH level and GST (liver) activities in Wistar male rats fed control and treatment diets. The levels of antioxidant glutathione ranged from a low of $137.86 \mu \mathrm{M}(\mathrm{HFD} / \mathrm{HS}+$ Turmeric $1 \%)$ to a high $(p \leq 0.05)$ of GSH at $500 \mu \mathrm{M}(\mathrm{HFD} / \mathrm{HS}+$ Garlic $2 \%)$. Both turmeric and garlic incorpo- 
rated diets resulted in a 2 -fold increase (dose response) with increasing from $1 \%$ to $2 \%$ level. Rats fed the control diet were seen to have lower levels of GSH compared to other treatment groups and was significantly $(p \leq 0.05)$ lower compared to rats fed diets with $2 \%$ garlic and $1 \%$ ginger. However, there was no significant induction of GST activity among control and treatment groups. Among spice-incorporated diets, 2\% diets seemed to result in higher GST activity compared to their $1 \%$ counterparts, with a 2 -fold increase in GST activity between $1 \% \& 2 \%$ turmeric fed rats. The primary function of GST is for the detoxification of xenobiotic compounds that are conjugated to glutathione; these compounds are then excreted from the organism [23]. Decreased levels of GSH have been reported among individuals with diabetes [24] [25] [26].

Serum cholesterol levels in Wistar rats are shown in Figure 9. Cholesterol levels ranged from a low of $67 \mathrm{mg} / \mathrm{dL}$ (control) to a high of $146 \mathrm{mg} / \mathrm{dL}$ (HFD/HS). There was a significant $(p \leq 0.05)$ increase in cholesterol levels in all treatment groups compared to that of the control (normal fat \& sugar). Among rats fed spice-incorporated diets, rats fed ginger exhibited lowest cholesterol levels. Rats fed spice incorporated diets resulted in significantly $(p \leq 0.05)$ lower cholesterol levels compared to HFD/HS fed rats with the exception of rats fed turmeric $2 \%$.

\section{Conclusion}

In vivo pre-diabetic model was utilized for the assessment of the effects of incorporating, garlic, turmeric, and ginger at select concentrations using high fat and sugar diets on Wistar male rats. This study explored the effects of thermally treated TGG on male wistar rats using a pre-diabetic (HFD/HS) model for 11 weeks. Unhealthy dietary and lifestyle patterns for extended periods of time may lead to the development of both pre-diabetes and Type 2 Diabetes. Our study showed that diets that incorporated TGG had lower weight gain compared to rats fed HFD/HS alone. Additionally, rats fed spice-incorporated diets showed a

$1 \%=2 \%$

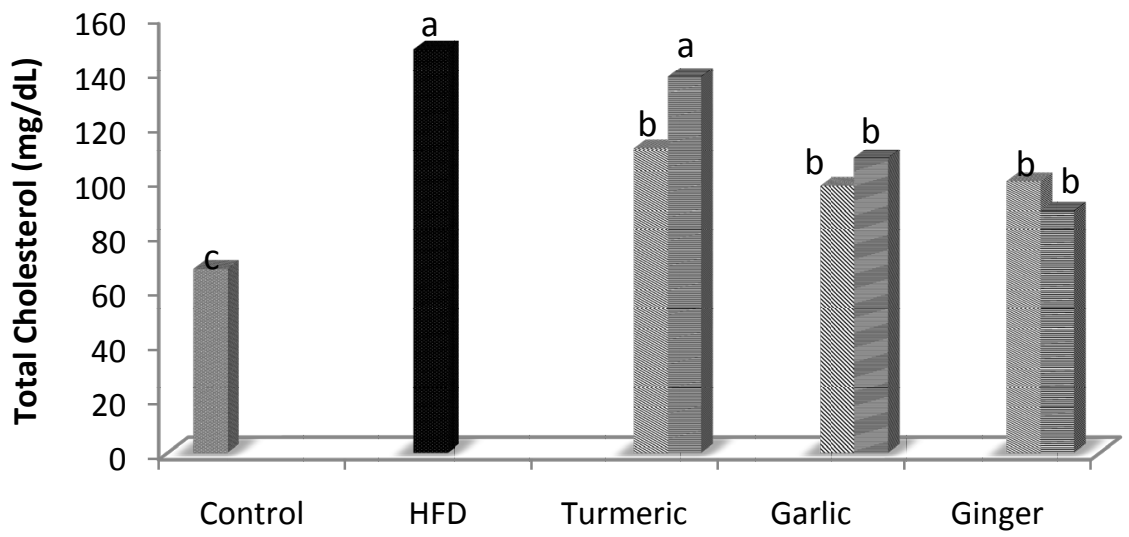

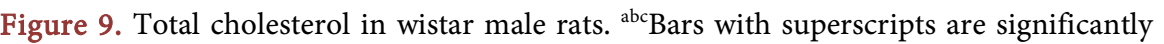
different $(p \leq 0.05)$. Abbreviations: HFD = High fat diet. 
gradual reduction in serum glucose and cholesterol levels over time. Research [27] [28] [29] suggest that these anti-diabetic properties exhibited by spices may be attributed to the ability of spices to delay gastric emptying, reduce glucose absorption, and reducing inflammation by inactivating the pro-inflammatory factor NFk- $\beta$ via its Ik- $\beta$ inhibitor. Induction of selected enzymes' (CAT, SOD, GPx, GST) serve as internal health promoting functions that combat ROS and may prevent cellular damage. Phytochemicals within spices may aid in the activation of these detoxifying enzymes. Rats fed TGG diets showed lower activities of GPx and GST along with increased levels of GSH.

\section{Acknowledgements}

Funding for this research was provided by the Alabama Agricultural Experimental Research Station, Title III, and USDA/CBG Grant.

\section{References}

[1] Ademiluyi, A. and Oboh, G. (2013) Soybean Phenolic Rich Extracts Inhibit Key Enzymes Linked to Type 2 Diabetes ( $\alpha$-Amylase and $\alpha$-Glucosidase) and Hypertension (Angiotensin I Converting Enzyme) in Vitro. Experimental Toxicological Pathology, 65, 305-309. https://doi.org/10.1016/j.etp.2011.09.005

[2] World Health Organization (WHO) (2009) WHO Monographs on Selected Medicinal Plants: Volume 4.

http://www.who.int/medicines/areas/traditional/SelectMonoVol4.pdf

[3] Centers for Disease Control and Prevention (2014) National Diabetes Statistics Report: Estimates of Diabetes and Its Burden in the United States, 2014. US Department of Health and Human Services, Atlanta, GA.

[4] Babey, S., Wolstein, J., Diamant, A. and Goldstein, H. (2016) Prediabetes in California: Nearly Half of California Adults on Path to Diabetes. Policy Brief (UCLA Center for Health Policy Research), (PB2016-1), 1-8.

[5] Cordain, L., Eaton, S., Sebastian, A., Mann, N., Lindeberg, S., Watkins, B., O’Keefe, J. and Brand-Miller, J. (2005) Origins and Evolution of the Western Diet: Health Implications for the 21st Century. The American Journal of Clinical Nutrition, 81, 341-354. https://doi.org/10.1093/ajcn.81.2.341

[6] Hu, F. (2011) Globalization of Diabetes: The Role of Diet, Lifestyle, and Genes. Diabetes Care, 34, 1249-1257. https://doi.org/10.2337/dc11-0442

[7] Rao, B. (2003) Bioactive Phytochemicals in Indian Foods and Their Potential in Health Promotion and Disease Prevention. Asia Pacific Journal of Clinical Nutrition, 12, 9-22.

[8] Vincent, H., Bourguignon, C. and Taylor, A. (2010) Relationship of the Dietary Phytochemical Index to Weight Gain, Oxidative Stress and Inflammation in Overweight Young Adults. Journal of Human Nutrition and Dietetics, 23, 20-29. https://doi.org/10.1111/j.1365-277X.2009.00987.x

[9] Bazzano, L., Serdula, M. and Liu, S. (2005) Prevention of Type 2 Diabetes by Diet and Lifestyle Modification. Journal of the American College of Nutrition, 24, 310-319. https://doi.org/10.1080/07315724.2005.10719479

[10] Mofleh, I. (2010) Spices Herbal Xenobiotics and the Stomach: Friends or Foes? World Journal of Gastroenterology, 16, 2710-2719.

https://doi.org/10.3748/wjg.v16.i22.2710 
[11] Sen, S., Chakraborty, R., Sridhar, C., Reddy, Y. and De, B. (2010) Free Radicals, Antioxidants, Diseases and Phytomedicines: Current Status and Future Prospect. International Journal of Pharmaceutical Sciences Review and Research, 3, 91-100.

[12] Iyer, A., Panchal, S, Poudyal, H. and Brown, L. (2009) Potential Health Benefits of Indian Spices in the Symptoms of Metabolic Syndrome: A Review. Indian Journal of Biochemistry and Biophysics, 46, 467-481.

[13] Madkor, H., Mansour, S. and Ramadan, G. (2011) Modulatory Effects of Garlic, Ginger, Turmeric and Their Mixture on Hyperglycaemia, Dyslipidaemia and Oxidative Stress in Streptozotocin-Nicotinamide Diabetic Rats. British Journal of Nutrition, 105, 1210-1217. https://doi.org/10.1017/S0007114510004927

[14] Al-Suhaimi, E., Al-Riziza, N. and Al-Essa, R. (2011) Physiological and Therapeutical Roles of Ginger and Turmeric on Endocrine Functions. The American Journal of Chinese Medicine, 39, 215-231. https://doi.org/10.1142/S0192415X11008762

[15] Li, L., Wang, Z., Ying, X., Mao, J., Sun, T., Tian, J. and Yang, K. (2012) Garlic for Diabetes Mellitus. The Cochrane Library. https://doi.org/10.1002/14651858.CD009981

[16] Eidi, A., Eidi, M. and Esmaeili, E. (2006) Antidiabetic Effect of Garlic (Allium sativum L.) in Normal and Streptozotocin-Induced Diabetic Rats. Phytomedicine, 13, 624-629. https://doi.org/10.1016/j.phymed.2005.09.010

[17] Wongsa, P., Chaiwarit, J. and Zamaludien, A. (2012) In Vitro Screening of Phenolic Compounds, Potential Inhibition against $\alpha$-Amylase and $\alpha$-Glucosidase of Culinary Herbs in Thailand. Food Chemistry, 131, 964-971. https://doi.org/10.1016/j.foodchem.2011.09.088

[18] Reeves, P., Nielsen, F. and Fahey, G. (1993) AIN-93 Purified Diets for Laboratory Rodents: Final Report of the American Institute of Nutrition Ad Hoc Writing Committee on the Reformulation of the AIN-76A Rodent Diet. Journal of Nutrition, 123, 1939-1951. https://doi.org/10.1093/jn/123.11.1939

[19] Reinhold, J.G., Faradji, B., Abadi, P. and Ismail-Beigi, F. (1976) Decreased Absorption of Calcium, Magnesium, Zinc and Phosphorus by Humans due to Increased Fiber and Phosphorus Consumption as Wheat Bread. The Journal of Nutrition, 106, 493-503. https://doi.org/10.1093/jn/106.4.493

[20] Bosscher, D., Van Caillie-Bertrand, M., Van Cauwenbergh, R. and Deelstra, H. (2003) Availabilities of Calcium, Iron, and Zinc from Dairy Infant Formulas Is Affected by Soluble Dietary Fibers and Modified Starch Fractions. Nutrition, 19, 641-645. https://doi.org/10.1016/S0899-9007(03)00063-7

[21] Wohaieb, S. and Godin, D. (1987) Alterations in Free Radical Tissue-Defense Mechanisms in Streptozocin-Induced Diabetes in Rat: Effects of Insulin Treatment. Diabetes, 36, 1014-1018. https://doi.org/10.2337/diab.36.9.1014

[22] Suryanarayana, P., Satyanarayana, A., Balakrishna, N., Kumar, P.U. and Reddy, G.B. (2007) Effect of Turmeric and Curcumin on Oxidative Stress and Antioxidant Enzymes in Streptozotocin-Induced Diabetic Rat. Medical Science Monitor, 13, BR286-BR292.

[23] Angelucci, F., Baiocco, P., Brunori, M., Gourlay, L., Morea, V. and Bellelli, A. (2005) Insights into the Catalytic Mechanism of Glutathione S-Transferase: The Lesson from Schistosoma haematobium. Structure, 13, 1241-1246. https://doi.org/10.1016/j.str.2005.06.007

[24] Kalkan, I. and Suher, M. (2013) The Relationship between the Level of Glutathione, Impairment of Glucose Metabolism and Complications of Diabetes Mellitus. 
[25] Li, Y., Tran, V., Duke, C. and Roufogalis, B. (2012) Preventive and Protective Properties of Zingiber officinale (ginger) in Diabetes Mellitus, Diabetic Complications, and Associated Lipid and Other Metabolic Disorders: A Brief Review. Evidence-Based Complementary and Alternative Medicine, 2012, Article ID: 516870. https://doi.org/10.1155/2012/516870

[26] Sekhar, R., Patel, S., Guthikonda, A., Reid, M., Balasubramanyam, A., Taffet, G. and Jahoor, F. (2011) Deficient Synthesis of Glutathione Underlies Oxidative Stress in Aging and Can Be Corrected by Dietary Cysteine and Glycine Supplementation. The American Journal of Clinical Nutrition, 94, 847-853.

https://doi.org/10.3945/ajcn.110.003483

[27] Srinivasan, K. (2005) Spices as Influencers of Body Metabolism: An Overview of Three Decades of Research. Food Research International, 38, 77-86.

https://doi.org/10.1016/j.foodres.2004.09.001

[28] Rani, M., Padmakumari, K., Sankarikutty, B., Cherian, O., Nisha, V. and Raghu, K. (2011) Inhibitory Potential of Ginger Extracts against Enzymes Linked to Type 2 Diabetes, Inflammation and Induced Oxidative Stress. International Journal of Food Sciences and Nutrition, 62, 106-110. https://doi.org/10.3109/09637486.2010.515565

[29] Kirkham, S., Akilen, R., Sharma, S. and Tsiami, A. (2009) The Potential of Cinnamon to Reduce Blood Glucose Levels in Patients with Type 2 Diabetes and Insulin Resistance. Diabetes, Obesity and Metabolism, 11, 1100-1113.

https://doi.org/10.1111/j.1463-1326.2009.01094.x 